\title{
Effects of Mask Pack Containing Yam Bean (Pachyrhizus erosus) Extracts on Skin Improvement
}

\author{
Ah Reum Lee ${ }^{1}$, Hae-Ok Kim², Weon Jung Song ${ }^{3}$, Yu-Hong Min ${ }^{4}$, Seong-Soo Roh ${ }^{1 *}$ \\ ${ }^{1}$ College of Korean Medicine, Daegu Haany University, Daegu, Korea \\ ${ }^{2}$ Department of Nursing, Kyungnam University, Changwon-si, Gyeongsangnam-do, Korea \\ ${ }^{3}$ Sangju-si Agricultural Technology Center, Sangju-si, Gyeongsangbuk-do, Korea \\ ${ }^{4}$ Department of Beauty Care, Daegu Haany University, Gyeongsan-si, Gyeongsangbuk-do, Korea
}

\author{
Corresponding author: Seong-Soo Roh, \\ College of Korean Medicine, Daegu Haany \\ University, 136 Sincheondong-ro, \\ Suseong-gu, Daegu 42158, Korea \\ Tel.: +82537702351 \\ Fax: +82 537686340 \\ Email: ddede@dhu.ac.kr
}

Received February 10, 2017

Revised April 15, 2017

Accepted April 19, 2017

Published June 30, 2017



\begin{abstract}
Purpose: We had previously demonstrated that yam bean (Pachyrhizus erosus) extracts have anti-oxidant and anti-melanogenic effects. Accordingly, the present study explored skin improvements resulting from the use of a mask pack containing yam bean extracts. Methods: Subjects included 15 women in their 20s who met the selection and exclusion criteria. Subjects applied the mask pack three times a week for 5 weeks. To determine the effects of the mask pack on the skin, we measured oil, moisture, and melanin content as well as erythema of the facial skin once a week for 5 weeks (i.e., a total of five measurements). Results: After using the mask pack for 5 weeks, the moisture and oil content of the facial skin increased. In addition, the erythema and melanin content significantly decreased. Furthermore, the subjects were highly satisfied with the improvement in skin conditions such as dryness and skin tone. Conclusion: Our results indicate that a mask pack containing yam bean extracts has beneficial effects on facial skin, and it should be considered for use in new functional cosmetics.
\end{abstract}

Keywords: Yam bean, Mask pack, Oil content, Melanin content, Skin improvement

\section{Introduction}

개인의 외모는 첫인상을 결정짓는 매우 중요한 부분이며, 현대사 회에서 대인관계를 형성하는 데에 있어 큰 역할을 차지한다. 외모 관리는 미용의 개념을 넘어 현대인의 경쟁력으로 자리매김하고 있 고(Hassin \& Trope, 2000), 이에 따라 피부를 아름답게 관리하고자 하는 욕구는 점차 높아져 가고 있다(Jang et al., 2011).

피부를 관리하는 데에는 많은 방법이 있는데, 그 중 팩을 이용한 피부관리법은 사용법이 간단하고 시간에 구애 받지 않으며 경제적 부담이 적어 쉽게 접근할 수 있다(Kim \& Chung, 2013). 팩은 피부 에 영양물질을 공급하여 피부상태를 개선해주는 제품으로 피부와 외부 공기가 통할 수 있으며 굳어지지 않는다는 특징이 있다. 이에 비하여 마스크는 시간이 진행됨에 따라 굳어져 외부와 공기가 통하 지 않으며 수분 증발을 차단하고 영양물질의 흡수를 돕는다. 우리
나라에서는 팩과 마스크가 같은 의미로 통용되고 있으며 팩, 마스 크 또는 마스크 팩이라는 말로 불리고 있다(Lee et al., 2005).

최근에는 화장품 합성 성분들의 부작용 및 안전성 문제가 제기되고 (Lee et al., 2013), 또한 자연주의가 확산되면서 천연 소재를 활용한 팩 의 개발이 지속적으로 증가하고 있는 추세이다. 천연물에 함유된 활성 성분의 미백, 주름개선, 항염 등 다양한 피부 상태 개선 효능이 다수 보 고되었고(Jee, 2009; Park et al., 2015), 천연소재를 함유한 팩 제 제를 개발하려는 연구가 다양하게 진행되고 있다(Bae et al., 2012).

얌빈(Yam bean)은 히카마(jicama)라는 이름으로도 불리는 멕 시코 원산의 아열대성 콩과 식물로, 최근 국내에 도입되어 재배 되고 있다(Uhm et al., 2016). 본 연구자는 선행연구에서 얌빈 추 출물의 2,2-diphenyl-1-picrylhydrazyl (DPPH), 2,2'-azinobis (3-ethylbenzothiazoline-6-sulfonic acid) diammonium salt (ABTS) 라디칼 소거능, 페놀, 플라보노이드 함량을 측정하여 항산 
화 효능을 확인하였고, tyrosinase 억제 및 멜라닌 생합성 억제 활 성을 통하여 얌빈 추출물의 미백 기능성 소재로서 가능성을 시사하였다 (Loe et al., 2017). 따라서 본 연구에서는 20대 성인 여성을 대상으로 얌빈 추출물이 함유된 마스크 팩을 5 주간 적용하여 유수분량, 홍반 량, 멜라닌 함량을 측정함으로써 피부개선효과를 검증하고자 한다.

\section{Methods}

\section{1. 얌빈 추출물 제조}

본 실험에서 사용한 얌빈은 경상북도 상주시에서 채취하여 실 험의 재료로 사용하였다. 얌빈 열수 추출물은 건조한 얌빈 $50 \mathrm{~g}$ 을 파쇄하여 증류수 $500 \mathrm{~mL}$ 에 넣고 $100^{\circ} \mathrm{C}$ 에서 $2 \mathrm{~h}$ 동안 가열한 후, 이를 여과지(Whatman ${ }^{\circledR}$ Qualitative Filter Papers No.2; GE Healthcare Life Sciences, USA)를 사용하여 여과하였다. 여과액을 rotary vacuum evaporator (N1100; EYELA, Japan)를 사용하여 감압농축 및 동결건조하여 마스크 팩의 재료로 사용하였다. 얌빈은 열수 추출하였을 때 $44.76 \%$ 의 수율을 나타내었다.

\section{2. 얌빈 추출물 함유 마스크 팩 제조}

정제수에 얌빈 추출물을 $0.30 \%$ 첨가한 후, 카라기난 파우더 (Eansoap, Korea) $0.12 \%$ 로 점도를 조절하여 마스크 팩을 제조하였다.

\section{3. 연구 대상자}

연구 대상자 선정 방법은 Park \& Jeong (2012)의 방법을 수정하 여 본 실험에 적용하였다. 대상자는 20 대 여성으로 피부 질환이나 병력이 없으며 최근 6 개월 이내 피부 관리를 받지 않은 비흡연자를 대상으로 실시하였다.

\section{4. 실험 방법}

연구 대상자에게 얌빈 추출물 함유 겔 마스크 팩을 적용하여 5 주 간의 피부의 유수분량 및 피부톤 변화를 조사하였다. 연구 대상자 수

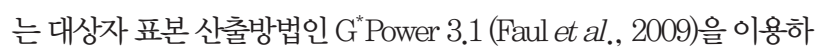
여 계산하였고, Cohen 공식에 의해 낮은 효과크기(f) 0.15 를 기준으 로, 유의수준 0.05 , 검정력 0.80 , 집단수 1 , 반복측정 회수 6 으로 했을 때 12 명씩 산출되었으나, 탈락율 $20 \%$ 를 감안하여 실험군 15 명을 선 정하였다. 연구 대상자에게 연구 배경, 목적, 방법(실험 기간 중 주의 사항, 피부 측정 방법 등)을 상세히 전달하고, 서면 동의서를 작성하 게 한 다음 실험을 진행하였다. 실험 기간은 5 주간 실시하며, 주 3 회 얌빈 추출물 함유 마스크 팩을 $10 \mathrm{~min}$ 이상 부착한 다음 매주 수요일 에 기기를 이용하여 피부 측정을 하였다. 피부 측정 방법은 Song et al. (2010)의 연구 방법을 수정하여 본 실험에 적용한 것으로 실험 당 일 동일한 클렌징 제품으로 세안하고 $1 \mathrm{~h}$ 후 T-zone과 U-zone의 유 분과 수분, 홍반량, 멜라닌량을 측정하였고, 연구 측정 및 진행은 측 정 조건을 동일하게 하고자 온도 $24 \pm 1^{\circ} \mathrm{C}$, 습도 $55 \pm 10 \%$ 로 실내 환 경을 일정하게 하였다. 모든 실험 과정은 경남대학교 생명윤리위원 회의 승인을 받아 실시하였다(승인번호: KUIRB-03-01).

\section{5. 피부 상태 측정 방법}

연구 대상자의 피부 유분량은 Sebumeter ${ }^{\circledR}$ (SM 815; Courage+ Khazaka Electronic, Germany), 수분량은 Corneometer ${ }^{\circledR}$ (CM 825; Courage+Khazaka Electronic), 홍반량 및 멜라닌량은 Mexameter $^{\circledR}$ (MX 18; Courage+Khazaka Electronic)을 사용하여 측정하였다. 각 기기의 사용은 기기의 매뉴얼에 따라 실시하였다.

안면의 T-zone 부위는 이마에서 양 눈썹 머리를 잇는 미간 중 앙에서 상부 $1 \mathrm{~cm}$ 위쪽(1), $\mathrm{FH}$ )과 양 코볼 우측(2), RT), 좌측(3), $\mathrm{LT})$ 을 측정기로 $3-5 \mathrm{~s}$ 동안 접촉하여 측정하였다. U-zone은 양

Table 1. General features of test subjects

\begin{tabular}{llcc}
\hline & Category & Frequency $(\mathrm{N})$ & Percentage (\%) \\
& Less than $500 \mathrm{cc}$ & 1 & 6.7 \\
Water intake & $500-1000 \mathrm{cc}$ & 9 & 60.0 \\
& $1000-1500 \mathrm{cc}$ & 5 & 33.3 \\
& More than $1500 \mathrm{cc}$ & 0 & 0.0 \\
& Less than $5 \mathrm{~h}$ & 0 & 0.0 \\
Sleeping hours & $5-6 \mathrm{~h}$ & 7 & 46.7 \\
& $7-8 \mathrm{~h}$ & 6 & 40.0 \\
& More than $9 \mathrm{~h}$ & 2 & 13.3 \\
& Don't drink & 11 & 73.3 \\
& Once or twice a week & 4 & 26.7 \\
& 3-4 times a week & 0 & 0.0 \\
& More than 5 times a week & 0 & 100.0 \\
\hline
\end{tabular}




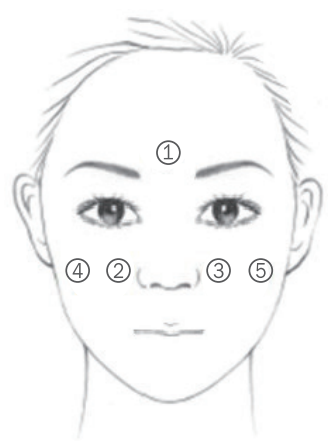

Figure 1. Measurement site on the face.

Oil, moisture, erythema, and melanin content were measured at five sites on the face. (1), forehead (FH); (2), right of T-zone (RT); (3), left of T-zone (LT); (4), right of U-zone (RU); (5), left of U-zone (LU).
코볼에서 수평으로 긋고 눈꼬리에서 수직으로 내려와 맞닿는 곳 (4), RU; (5), LU)을 기기로 $3-5 \mathrm{~s}$ 간 접촉하여 측정하였다(Figure 1).

\section{6. 통계 분석}

실험에서 얻어진 결과는 Microsoft Office Excel 2010 (Microsoft, USA)을 이용하여 분석하였다. 연구 대상자의 일반적 특성에 대한 설문은 각 응답에 대한 빈도와 전체에 대한 백분율을 구하여 결 과를 산출하였다. 피부의 수분, 유분, 피부톤은 $\mathrm{t}-\mathrm{test}$ 를 통해 $p$ 값을 산출하여 통계적 유의성 검증을 실시하고, 연구 결과에 대 한 실증분석은 $p<0.05$ 일 때 통계적으로 유의하다고 판단하였다. 실험 종료 후, 설문을 통한 제품에 대한 만족도를 각 응답에 대한 빈도를 점수로 환산하여 결과를 산출하였다.

Table 2. Subjective skin condition categories of test subjects

\begin{tabular}{|c|c|c|c|}
\hline \multicolumn{2}{|c|}{ Category } & Frequency (N) & Percentage (\%) \\
\hline \multirow{6}{*}{ Skin type } & Oily & 2 & 13.3 \\
\hline & Dry & 3 & 20.0 \\
\hline & Normal & 2 & 13.3 \\
\hline & Combination & 8 & 53.3 \\
\hline & Sensitive & 0 & 0.0 \\
\hline & Acne & 0 & 0.0 \\
\hline \multirow{5}{*}{ Skin tone } & Very bright & 0 & 0.0 \\
\hline & Bright & 2 & 13.3 \\
\hline & Normal & 9 & 60.0 \\
\hline & Dark & 4 & 26.7 \\
\hline & Very dark & 0 & 0.0 \\
\hline \multirow{5}{*}{ Moisture } & Dry & 0 & 0.0 \\
\hline & Semi-dry & 9 & 60.0 \\
\hline & Normal & 3 & 20.0 \\
\hline & Slightly moist & 1 & 6.7 \\
\hline & Very moist & 2 & 13.3 \\
\hline \multirow{5}{*}{ Softness } & Rough & 1 & 6.7 \\
\hline & Slightly rough & 4 & 26.7 \\
\hline & Normal & 7 & 46.7 \\
\hline & Slightly soft & 2 & 13.3 \\
\hline & Very soft & 1 & 6.7 \\
\hline \multirow{6}{*}{ Corneous } & Not at all & 2 & 13.3 \\
\hline & Sometimes & 9 & 60.0 \\
\hline & Normal & 1 & 6.7 \\
\hline & More than usual & 3 & 20.0 \\
\hline & Frequently & 0 & 0.0 \\
\hline & Total & 15 & 100.0 \\
\hline
\end{tabular}




\section{Results and Discussion}

\section{1. 연구대상자의 일반적 특성}

본 실험의 참가자는 총 15 명으로서 평균 연령 $21.47 \pm 0.92$ 세의 여성을 대상으로 하였다. 평균 수분 섭취량은 500-1000 cc라는 답 변이 $60.0 \%$ 로 가장 높게 나타났으며, 평균 수면량은 5-6 h 피험 자가 $46.7 \%, 7-8 \mathrm{~h}$ 피험자가 $40.0 \%$ 로 나타났다. 음주는 체수분 의 균형을 깨뜨리며 수분을 세포 밖으로 끌어 내므로 피부를 거칠 게 하고 탄력을 저하시켜 실험의 변수가 될 수 있다(Lee \& Myong, 2002). 연구 대상자의 평균 음주 횟수를 설문지를 통하여 조사한 결 과 전혀 마시지 않는 연구대상자가 $73.3 \%$ 로 가장 많았고 주 1-2회 마시는 피험자가 $26.7 \%$ 로 나타났다(Table 1).

연구대상자의 주관적 피부상태를 크게 지성, 건성, 중성, 복합성, 민감성, 여드름성으로 나누었을 때, 복합성이라는 응답이 $53.3 \%$ 으 로 나타났고, 건성이라는 응답이 $20.0 \%$ 으로 나타났다. 지성 및 중 성이라는 대답은 $13.3 \%$ 였고, 민감성 및 여드름성 피부는 없었다. 피부 상태를 묻는 문항에서 피부톤은 보통이 $60.0 \%$ 으로 가장 많았 고 어두운 피부라는 응답이 $26.7 \%$ 로 나타나 전체적으로 보통이거 나 어두운 피부를 가진 연구대상자가 많은 것으로 파악되었다. 촉 촉함의 정도는 가끔 건조하다라는 답이 $60.0 \%$ 으로 가장 높았으며, 부드러움 정도를 묻는 문항에서는 보통이라는 답변이 $46.7 \%$ 로 가 장 높았고, 그 다음은 부드럽지 않다는 답변이 $26.7 \%$ 로 나타났다. 각질의 정도는 가끔 일어난다는 답변이 $60.0 \%$ 로 가장 높게 나타났 고 보통보다 많다는 답변이 $20.0 \%$ 로 나타났다(Table 2).

\section{2. 유수분 변화량}

피부 표면의 유분량은 피부 표면의 수분 손실을 막아주고, 피부 의 낮은 산도 $(\mathrm{pH})$ 를 유지하여 피부를 보호하는 기능을 한다(Rou \& Park, 2004). 얌빈 추출물을 함유한 마스크 팩을 5 주 적용하였을 때 피부의 유분량은 이마, T-zone, U-zone 모두에서 증가하였다. $\mathrm{T}$-zone의 왼쪽(LT)은 $52.80 \pm 42.43$ 에서 5 주 후 $110.50 \pm 47.84$ 로

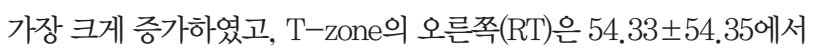

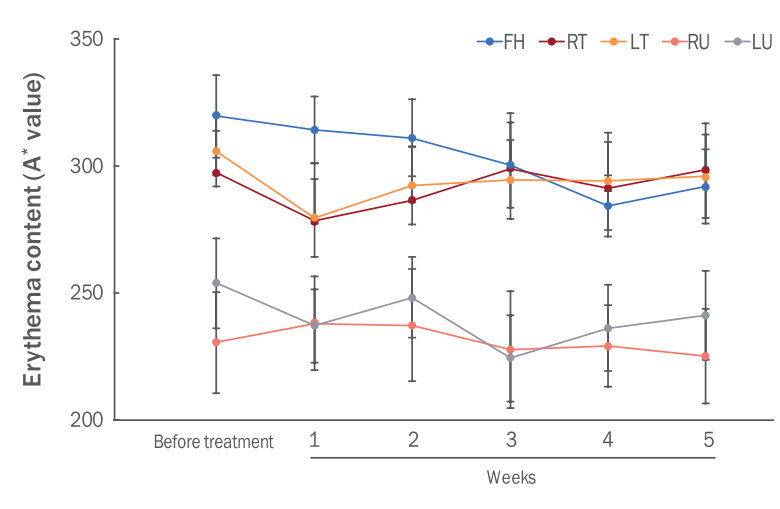

Figure 2. Change of erythema content through treatment with mask pack containing yam bean extracts.

Erythema content was measured by Mexameter ${ }^{\circledR}$ at the designated sites on the face. The graph indicates the mean and standard deviation of erythema content for 5 weeks. Erythema (skin redness) was improved through treatment with mask pack containing yam bean extracts. $\mathrm{FH}$, forehead; RT, right of T-zone; $\mathrm{LT}$, left of T-zone; RU, right of U-zone; LU, left of U-zone.

5 주 후 106.29 244.32 로 두번째 순서로 증가하였다(Table 3).

피부는 10-20\% 정도의 수분을 함유하고 있어 부드럽고 매끄러 운 피부 외관을 유지하도록 돕는다. 수분이 $10 \%$ 이하가 되면 피부 가 건조하여 당김을 느끼거나, 주름이 생길 수 있다(Park et al., 2013). 또한 피부의 유수분량이 충분하지 않으면 각질층의 각화과 정을 원활히 일어나지 않게 되고 이에 따라 피부 착색지수를 증가 하게 하여 칙칙하고 어두운 피부톤을 만든다(Kim \& Kim, 2009). 따라서 수분함유량을 늘리고 수분증발을 막아 정상피부를 유지 하는 것이 매우 중요하다. 얌빈 추출물을 함유한 마스크 팩을 5 주 간 적용하였을 때 피부의 수분량은 이마 $(\mathrm{FH})$ 에서 측정하였을 때 $53.08 \pm 13.71$ 에서 $62.06 \pm 8.62$ 으로 증가하였고, U-zone의 오른 쪽(RU), 왼쪽(LU)의 수분량 또한 증가하였다. T-zone에서는 수 분량이 다소 감소하는 모습을 나타냈으나 LT의 유의성은 없었다 (Table 4), 연구 결과를 종합해보았을 때, 얌빈 추출물 함유 겔 마스

Table 3. Change in oil content of facial skin

\begin{tabular}{|c|c|c|c|c|c|c|c|}
\hline $\begin{array}{l}\text { Measurement } \\
\text { site of face }\end{array}$ & $\begin{array}{c}\text { Before } \\
\text { treatment }\end{array}$ & 1 week & 2 weeks & 3 weeks & 4 weeks & 5 weeks & Average of change \\
\hline $\mathrm{FH}$ & $60.27 \pm 38.08^{1)}$ & $94.80 \pm 28.03^{* *}$ & $103.33 \pm 68.27^{*}$ & $108.53 \pm 41.59^{* *}$ & $84.47 \pm 26.26$ & $107.64 \pm 47.53^{* *}$ & $46.00 \pm 39.86$ \\
\hline RT & $54.33 \pm 54.35$ & $88.53 \pm 55.48$ & $79.27 \pm 37.83$ & $99.67 \pm 47.85^{*}$ & $88.27 \pm 41.66$ & $106.29 \pm 44.32^{*}$ & $49.93 \pm 66.06$ \\
\hline LT & $52.80 \pm 42.43$ & $78.87 \pm 56.71$ & $91.20 \pm 68.52$ & $87.27 \pm 35.35^{*}$ & $79.27 \pm 29.99$ & $110.50 \pm 47.84^{* *}$ & $53.73 \pm 52.67$ \\
\hline $\mathrm{RU}$ & $24.07 \pm 18.68$ & $58.80 \pm 36.91^{* *}$ & $55.13 \pm 36.46^{* *}$ & $54.60 \pm 33.22^{* *}$ & $57.53 \pm 31.79^{* *}$ & $75.71 \pm 33.38^{* * *}$ & $48.80 \pm 29.84$ \\
\hline $\mathrm{LU}$ & $30.80 \pm 25.50$ & $54.60 \pm 37.24$ & $57.27 \pm 35.42^{*}$ & $58.27 \pm 34.96^{*}$ & $56.60 \pm 39.78^{*}$ & $74.07 \pm 40.26^{* *}$ & $40.67 \pm 36.48$ \\
\hline $\mathrm{M} \pm \mathrm{S} . \mathrm{D}$. & $44.45 \pm 15.96$ & $75.12 \pm 17.81^{*}$ & $77.24 \pm 21.02^{*}$ & $81.67 \pm 24.28^{*}$ & $73.23 \pm 15.10^{*}$ & $94.84 \pm 18.28^{* *}$ & $47.83 \pm 4.87$ \\
\hline
\end{tabular}

${ }^{1)}$ All values are $M \pm$ S.D. of 15 subjects' oil content for facial skin.

Significance: ${ }^{*} p<0.05 ;{ }^{* *} p<0.01 ;{ }^{* * *} p<0.001$ compared with before treatment.

$\mathrm{M} \pm$ S.D., mean \pm standard deviation. 


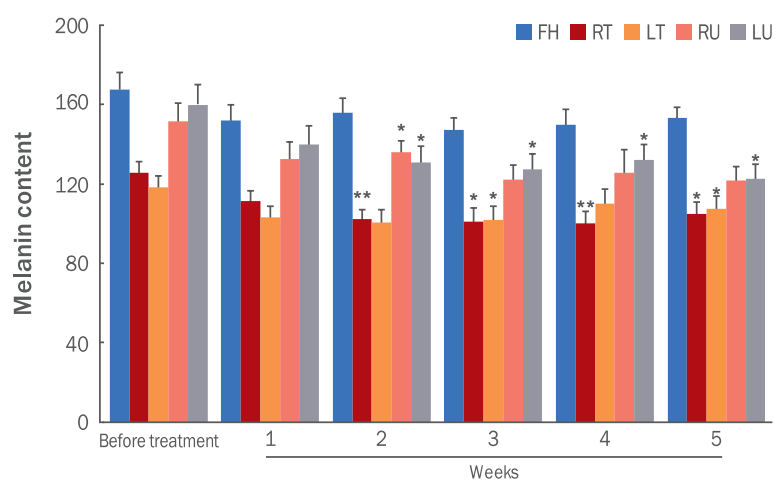

Figure 3. Change of melanin content through treatment with mask pack containing yam bean extracts.

Melanin content was measured by Mexameter ${ }^{\circledR}$ at the designated sites on the face for 5 weeks. The graph shows the decrease of the melanin content through treatment with mask pack containing yam bean extracts. FH, forehead; RT, right of T-zone; LT, left of T-zone; RU, right of U-zone; LU, left of U-zone. Significance: ${ }^{*} p<0.05,{ }^{* *} p<0.01$ compared with before treatment.

크 팩은 유분량을 증가시켰으나 수분량은 크게 변화가 없었다. 피 부의 수분량은 화장품을 도포한 직후에는 상승하지만, 도포 $1 \mathrm{~h}$ 후 부터는 급격히 떨어지는 현상을 나타낸다(Kim, 2012). 이것은 피 부의 수분 증발을 막아주는 밀폐제(occlusive agent) 성분을 함유하 고 있지 않기 때문이다. 따라서 페트롤라툼(petrolatum)과 같은 밀 폐제를 적용할 경우 얌빈 추출물 함유 겔 마스크 팩의 수분 지속력 을 향상시킬 수 있을 것으로 사료된다(Park et al., 2013).

\section{3. 홍반 변화량}

자외선은 비타민 D 생성을 통한 구루병 예방 등 긍정적인 기능 을 하지만, 만성적인 자외선 노출은 혈관을 확장하게 만들고, 혈류 가 증가함으로써 피부가 붉게 변하는 홍반을 유발한다. 이러한 홍 반이 지속되면 그에 대한 방어 기전으로 색소침착이 일어나게 된 다(Onaka, 2002). 또한 피부의 색은 멜라닌뿐만 아니라, 혈액 속
헤모글로빈에 의해 결정되기 때문에 피부의 홍반량을 측정하는 것 은 피부톤 개선 효능을 평가하는데 있어 중요한 지표가 될 수 있다 (Kim, 2003). 5주간 피부의 홍반량을 측정한 결과, $\mathrm{FH}$ 에서 319.67 \pm 62.53 이었던 홍반량이 $292.00 \pm 56.31$ 로 가장 크게 감소하였고,

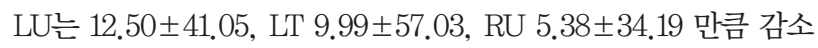
하였으나 RT에서는 큰 변화가 나타나지 않았다(Figure 2). 이러한 결과는 얌빈 추출물에 글루탐산(glutamic acid), 글리신(glycine), 히스티딘(histidine) 등과 같은 아미노산 성분이 풍부하여 피부 보 호 및 재생 기능을 하여 피부의 홍반량이 감소한 것으로 사료된다 (Noman et al., 2007).

\section{4. 멜라닌 변화량}

멜라닌은 자외선으로부터 피부를 보호하는 기능을 하지만 만성 적으로 자외선에 노출될 때는 과도하게 멜라닌이 생성되게 되고 색소침착과 같은 미용상의 문제를 야기한다(Lee et al., 2016). 이 마, T-zone, U-zone에서 멜라닌 변화량을 측정한 결과, 모두 일 정하게 감소함을 확인하였다. 구체적으로 LU는 $158.53 \pm 39.20$ 에 서 $121.71 \pm 25.70$ 으로 $34.13 \pm 36.00$ 만큼 감소하여 가장 크게 감 소함을 확인하였고, $\mathrm{LT}$ 가 가장 적게 감소하였으나, 이 또한 10.20 \pm 22.79 만큼 감소하여 얌빈 추출물 함유 마스크 팩의 미백 효능을 확인하였다(Figure 3). 이는 얌빈 추출물의 강력한 티로시나제 억 제활성 및 멜라닌 생합성 억제효능으로 인하여 색소침착의 감소가 있었을 것으로 사료된다(Lukitaningsih et al., 2013).

\section{5. 피부상태 주관적 만족도}

실험 전·후, 피부상태개선 여부에 관한 설문조사에서 연구 대상자가 느끼는 피부의 건조함은 실험 전 '좋지 않다'는 답변이 $33.3 \%$ 로 비교적 높게 나타났고, 실험 후에는 '좋다’ 답변이 $53.3 \%$ 로 나타나 주관적으로 느끼는 건조함이 개선되었음을 확인하였다. 주름 정도는 ‘좋다', '보통이다’는 답변이 33.3\%으로 동일하게 나타 났으나, 실험 후에는 두 문항 모두 $40.0 \%$ 로 증가하였다. 이는 연구 대상자가 20대 여성인 점을 감안하였을 때, 표정으로 인한 주름으

Table 4. Change in moisture content of facial skin

\begin{tabular}{|c|c|c|c|c|c|c|c|}
\hline $\begin{array}{l}\text { Measurement } \\
\text { site of face }\end{array}$ & $\begin{array}{c}\text { Before } \\
\text { treatment }\end{array}$ & 1 week & 2 weeks & 3 weeks & 4 weeks & 5 weeks & Average of change \\
\hline $\mathrm{FH}$ & $53.08 \pm 13.71^{1)}$ & $66.01 \pm 12.97^{*}$ & $66.11 \pm 9.83^{* *}$ & $65.99 \pm 10.04^{* *}$ & $64.29 \pm 10.80^{*}$ & $62.06 \pm 8.62$ & $8.35 \pm 14.36$ \\
\hline RT & $53.39 \pm 14.30$ & $49.56 \pm 16.02$ & $49.39 \pm 19.69$ & $55.95 \pm 18.15$ & $51.15 \pm 17.72$ & $38.99 \pm 14.64^{* *}$ & $-15.87 \pm 17.14$ \\
\hline LT & $55.57 \pm 15.82$ & $56.65 \pm 21.18$ & $53.66 \pm 21.35$ & $60.97 \pm 18.32$ & $53.13 \pm 22.68$ & $46.57 \pm 17.73$ & $-7.18 \pm 14.45$ \\
\hline $\mathrm{RU}$ & $63.29 \pm 15.44$ & $63.77 \pm 17.01$ & $70.31 \pm 14.69$ & $72.23 \pm 14.78$ & $67.89 \pm 15.43$ & $68.66 \pm 11.02$ & $5.84 \pm 17.41$ \\
\hline LU & $64.19 \pm 13.62$ & $70.66 \pm 16.49$ & $69.14 \pm 17.40$ & $73.75 \pm 12.57$ & $71.76 \pm 11.26$ & $70.49 \pm 10.13$ & $7.12 \pm 15.38$ \\
\hline $\mathrm{M} \pm \mathrm{S} . \mathrm{D}$. & $57.90 \pm 5.42$ & $61.33 \pm 8.30$ & $61.12 \pm 10.56$ & $65.78 \pm 7.50$ & $61.64 \pm 9.10$ & $57.35 \pm 13.93$ & $-0.34 \pm 10.69$ \\
\hline
\end{tabular}

${ }^{1)}$ All values are $\mathrm{M} \pm$ S.D. of 15 subjects' moisture content for facial skin.

Significance: ${ }^{*} p<0.05 ;{ }^{* *} p<0.01 ;{ }^{* * *} p<0.001$ compared with before treatment.

$\mathrm{M} \pm$ S.D., mean \pm standard deviation. 
로 사료된다. 탄력 정도를 묻는 문항에서 실험 전에는 ‘좋다’는 답 변과 ‘보통이다’라는 답변이 각각 $33.3 \%$ 로 가장 높게 나타났고, 실 험 후에는 '좋다라는 답변이 $40.0 \%$ 로 높게 나타나 탄력 정도가 개 선된 것을 확인하였다. 피부톤 정도에서는 '좋지 않다'라는 답변이 $33.3 \%$ 로 높게 나타났으나, 얌빈 추출물 함유 마스크 팩 사용 이후 에는 ‘좋다라는 답변이 $53.3 \%$ 로 나타나 피부의 멜라닌량 측정 결 과와 일치함을 확인하였다(Table 5).

\section{Conclusion}

본 연구에서는 얌빈 추출물을 함유한 겔 마스크 팩을 20 대 여성 에게 5 주간 적용한 뒤 피부에서의 유분량, 수분량, 홍반량, 멜라닌 량을 평가하고 설문조사를 통하여 주관적 피부상태개선 여부를 평 가하였다.

얌빈 마스크 팩 적용 전의 유분량은 평균 $44.45 \pm 15.96$ 를 나타 냈으나 5 주 적용 후 $94.84 \pm 18.28$ 의 높은 변화량을 나타냈다. 수 분량 또한 이마, U-zone에서는 증가하였으나, T-zone에서는 다 소 감소하는 경향을 나타냈다. 홍반량은 대체적으로 감소하였고 특 히 이마에서 $319.67 \pm 62.53$ 에서 $292.00 \pm 56.31$ 로 $8.66 \%$ 감소하였
다. 멜라닌량은 평균적으로 $20.97 \pm 10.02$ 만큼 크게 감소하였으며, T-zone과 U-zone에서 유의성 있는 감소를 보였다. 따라서 얌빈 추출물을 함유한 겔 마스크 팩을 적용하였을 때, 유분량이 증가하 여 매끄러운 피부가 되도록 도와주는 것을 확인하였고, 20 대 여성 뿐 아니라 유분량이 감소하여 쉽게 건조함을 느끼는 40-50대 여성 에게도 적합할 수 있다는 가능성을 시사하였으며, 특히 홍반량 및 멜라닌량은 얌빈 추출물 함유 겔 마스크 팩에 의하여 크게 감소하 여 뛰어난 미백 기능성을 임상실험에서 확인할 수 있었다.

설문을 통한 주관적 피부상태 개선여부에서는 실험 전 건조함 의 정도에서 건조함을 느낀다('좋지 않다')는 답변이 $33.3 \%$ 로 비교 적 높게 나타났으나, 실험 후에는 '좋다라는 답변이 $53.3 \%$ 로 나타 났으며, '우수하다라는 답변도 $20.0 \%$ 로 나타났다. 따라서 얌빈 추 출물 함유 마스크 팩을 통하여 연구 대상자의 주관적 피부의 건조 함이 개선된 것을 확인하였다. 피부톤은 ‘좋지 않다’라는 답변이 $33.3 \%$ 로 높게 나타났으나, 얌빈 추출물 함유 마스크 팩 사용 이후 에는 ‘좋다’라는 답변이 $53.3 \%$ 로 나타나 피부의 멜라닌량 측정 결 과와 일치함을 확인하였다.

본 연구 결과는 얌빈 추출물을 함유한 겔 마스크 팩을 적용하였 을 때 피부의 유분량의 증가 및 멜라닌량, 홍반량 감소를 확인하여 얌빈 추출물이 임상적으로 피부 상태를 개선하고 특히 탁월한 미백

Table 5. Change in subjective skin condition provided by a mask pack containing yam bean extracts

\begin{tabular}{|c|c|c|c|c|c|}
\hline & \multirow{2}{*}{ Category } & \multicolumn{2}{|c|}{ Before treatment } & \multicolumn{2}{|c|}{ After treatment } \\
\hline & & Frequency $(\mathrm{N})$ & Percentage (\%) & Frequency (N) & Percentage (\%) \\
\hline \multirow{5}{*}{ Dryness } & Excellent & 1 & 6.7 & 3 & 20.0 \\
\hline & Good & 4 & 26.7 & 8 & 53.3 \\
\hline & Normal & 3 & 20.0 & 4 & 26.7 \\
\hline & Poor & 5 & 33.3 & 0 & 0.0 \\
\hline & Bad & 2 & 13.3 & 0 & 0.0 \\
\hline \multirow{5}{*}{ Wrinkles } & Excellent & 2 & 13.3 & 3 & 20.0 \\
\hline & Good & 5 & 33.3 & 6 & 40.0 \\
\hline & Normal & 5 & 33.3 & 6 & 40.0 \\
\hline & Poor & 3 & 20.0 & 0 & 0.0 \\
\hline & Bad & 0 & 0.0 & 0 & 0.0 \\
\hline \multirow{5}{*}{ Elasticity } & Excellent & 1 & 6.7 & 4 & 26.7 \\
\hline & Good & 5 & 33.3 & 6 & 40.0 \\
\hline & Normal & 5 & 33.3 & 5 & 33.3 \\
\hline & Poor & 4 & 26.7 & 0 & 0.0 \\
\hline & Bad & 0 & 0.0 & 0 & 0.0 \\
\hline \multirow{6}{*}{ Skin tone } & Excellent & 3 & 20.0 & 2 & 13.3 \\
\hline & Good & 2 & 13.3 & 8 & 53.3 \\
\hline & Normal & 3 & 20.0 & 5 & 33.3 \\
\hline & Poor & 5 & 33.3 & 0 & 0.0 \\
\hline & Bad & 2 & 13.3 & 0 & 0.0 \\
\hline & Total & 15 & 100.0 & 15 & 100.0 \\
\hline
\end{tabular}


기능성이 있음을 시사하였다. 본 연구의 제한점은 실험군 설정에 있어 얌빈 추출물을 함유하지 않은 겔 마스크 팩을 적용한 대조군 이 없어 팩 자체의 효과와 비교 연구를 할 수 없다는 점이며, 따라 서 향후 연구에서는 대조군에 대한 부분을 보완하여 연구가 이루어 져야 할 것이다. 또한 연구자는 본 연구 결과가 얌빈의 화장품 소재 기능성 연구 및 제품 개발의 기초자료로 활용되기를 기대한다.

\section{References}

Bae IS, Shim MJ, Lee JY, Kim YC. Application tests of Phellodendrin cortex water extract as functional cosmetic raw materials. Journal of Investigative Cosmetology, 8: 1-8, 2012.

Faul F, Erdfelder E, Buchner A, Lang AG. Statistical power analyses using $\mathrm{G}^{*}$ Power 3.1: tests for correlation and regression analyses. Behavior Research Methods, 41: 1149-1160, 2009.

Hassin R, Trope Y. Facing faces: studies on the cognitive aspects of physiognomy. Journal of Personality and Social Psychology, 78: 837-852, 2000.

Jang SN, Kim KL, Kim GS, Lee YM. The effect of facial treatment on the facial skin condition of women college students. Journal of the Korean Society of Esthetics \& Cosmeceutics, 6: 123-130, 2011.

Jee SO. Antioxidant activities and whitening effect of the mulberry (Morus alba L.) root bark extracts. Korean Journal of Plant Resources, 22: 145-151, 2009.

Kim KJ. Clustering of skin colors on Korean adult males and their preference colors. Journal of the Korean Society of Clothing and Textiles, 27: 1338-1349, 2003.

Kim KL, Kim JS. The effect of sebum and moisture condition of skin on the facial pigmentation. Asian Journal of Beauty and Cosmetology, 7: 103-115, 2009.

Kim MY, Chung JY. The research on the environment-friendly echo beauty: focused on the mask pack brand. A Journal of Brand Design Association of Korea, 11: 237-250, 2013.

Kim R. A study on hydration effects of oriental herb extracts contained basic cream. Asian Journal of Beauty and Cosmetology, 10: 399-404, 2012.

Lee AR, Kim GN, Kim HO, Song WJ, Roh SS. Antioxidant activity and melanin inhibitory effects of yambean (Pachyrhizus erosus) extract. The Korea Journal of Herbology, 32: 57-
64, 2017.

Lee AS, Myong EJ. A study on knowledge and behavior for skin health care: focusing on women in their 20s. Journal of the Korean Society of Cosmetology, 8: 105-120, 2002.

Lee B, Moon KM, Kim SJ, Kim SH, Kim DH, An HJ, Jeong JW, Kim YR, Son S, Kim MJ, et al. (Z)-5-(2,4-dihydroxybenzylidene) thiazolidine-2,4-dione prevents UVB-induced melanogenesis and wrinkle formation through suppressing oxidative stress in HRM-2 hairless mice. Oxidative Medicine and Cellular Longevity, 2016: 2761463, 2016.

Lee JY, Yang H, Choi WC. Study on the suitability of mud-pack development from argillite. Journal of the Korean Society of Cosmetology, 11: 73-85, 2005.

Lee SH, Lee S, Lee SJ, Lee SA, Kim O. Skin whitening and antioxidant effects of the natural herbal compounds. Journal of Animal Assisted Psychotherapy, 2: 35-41, 2013.

Lukitaningsih E, Bahi M, Holzgrabe U. Tyrosinase inhibition type of isolated compounds obtained from Pachyrhizus erosus. Aceh International Journal of Science and Technology, 2: 98-102, 2013.

Noman AS, Hoque MA, Haque MM, Pervin F, Karim MR. Nutritional and anti-nutritional components in Pachyrhizus erosus L. tuber. Food Chemistry, 102: 1112-1118, 2007.

Onaka T. The effect of ultra violet light on health. Fashion \& Textile Research Journal, 4: 310-316, 2002.

Park E, Kim GN, Kim HO. Effect of moisturizer containing avocado oil on the skin moisture and personal satisfaction of 20s female college students. Asian Journal of Beauty and Cosmetology, 11: 951-957, 2013.

Park JA, Jeong SH. Melanin inhibitory activity and changes in the melanin and erythema values of Rumex crispus $\mathrm{L}$. extracts. Asian Journal of Beauty and Cosmetology, 10: 291-297, 2012.

Park JO, Park JO, Joo CG. A study on whitening and antiinflammatory effects of Eriobotrya japonica leaf extracts with different extraction methods. Journal of the Society of Cosmetic Scientists of Korea, 41: 151-157, 2015.

Rou FR, Park YS. Comparison of determined skin types by different factors of facial skin hydration, sebum content and surface pH levels. Asian Journal of Beauty and Cosmetology, 2: 67-82, 2004.

Song JH, Kim BJ, Choi EJ. The actual status of face washing in women in their 20s and 30s and the influence of cleansing oil upon the improvement of their facial skin 
Yam Bean Extracts and Skin Improvement

dryness. Asian Journal of Beauty and Cosmetology, 8: 1120, 2010.

Uhm MJ, Kim CS, Jin SY, Kim EJ, Kim JM, Song YJ. Comparison on tuber characteristics and yield of yam bean (Pachyrhizus erosus) by the different cultivation types: direct seeding vs transplanting. Horticultural Science \& Technology, 34: 73-74, 2016. 


\section{국문초록}

\section{얌빈 추출물이 함유된 마스크 팩의 피부개선효과}

이아름 ${ }^{1}$, 김혜옥 $^{2}$, 송원정 $^{3}$, 민유홍 $^{4}$, 노성수 $^{1 *}$

${ }^{1}$ 대구한의대학교 한의과대학 본초약리학교실, 대구, 한국

${ }^{2}$ 경남대학교 간호학과, 경상남도 창원시, 한국

${ }^{3}$ 상주시 농업기술센터, 경상북도 상주시, 한국

${ }^{4}$ 대구한의대학교 뷰티케어산업학과, 경상북도 경산시, 한국

목적: 이전 연구에서 우리는 얌빈 추출물이 항산화 효과와 항 멜라닌 생성 효과가 있음을 보고하였다. 따라서 본 논문의 목적은 얌 빈 추출물이 함유된 마스크 팩의 피부개선 효과를 알아보기 위한 것이다. 방법: 연구대상자는 선별 기준을 충족한 20 대 여성을 대 상으로 하였다. 15 명의 연구대상자들은 얌빈 추출물 함유 마스크 팩을 5 주간 주 3 회 $10 \mathrm{~min}$ 이상 부착하였다. 그 후 피부의 유수분 량, 홍반량, 멜라닌량, 주관적인 피부상태개선 여부를 조사하였다. 결과: 얌빈 추출물이 함유된 마스크 팩을 5 주간 사용한 결과, 유 수분 함량이 대체적으로 증가되었고, 특히 홍반량, 멜라닌량은 유의하게 개선된 것을 확인하였다. 설문조사를 통한 주관적인 피부 상태 또한 건조함을 느끼는 증상과 색소침착에 관한 항목에서 높은 만족도를 나타내었다. 결론: 본 연구는 얌빈 추출물이 함유된 마스크 팩의 사용이 피부의 유수분량 및 홍반량, 멜라닌량을 개선한다고 판단되며, 얌빈 추출물이 임상적으로도 우수한 미용 소재 임을 시사한다.

핵심어: 얌빈, 마스크 팩, 유분량, 멜라닌량, 피부개선

\section{참고문헌}

김구자. 한국 성인 남성의 피부색 분류와 선호색에 대한 연구. 한국의류학회지, 27: 1338-1349, 2003.

김금란, 김주섭. 피부 유·수분 상태가 피부 착색지수에 미치는 영향. 아시안뷰티화장품학술지, 7: 103-115, 2009.

김란. 한방허브추출물을 첨가한 기본제형 크림에 의한 피부보습상태 변화 연구. 아시안뷰티화장품학술지, 10: 399-404,

2012.

김미영, 정재윤. 친환경소재의 에코뷰티에 관한 연구: 마스크 팩 브랜드를 중심으로. 브랜드디자인학연구, $11: 237-250$, 2013.

류화라, 박영숙. 안면 유분량, 수분량 및 $\mathrm{pH}$ 기준에서의 피부유형 판정 비교. 아시안뷰티화장품학술지, 2: 67-82, 2004.

박은아, 김교남, 김혜옥. 20 대 여대생을 대상으로 한 아보카도 오일 함유 보습제의 만족도 및 피부 보습에 미치는 효과. 아시

안뷰티화장품학술지, 11: 951-957, 2013.

박정옥, 박진오, 주철규. 추출 방법에 따른 비파엽 추출물의 미백 및 항염활성에 관한 연구. 대한화장품학회지, 41: 151-157, 2015. 박주아, 정숙희. 소리쟁이 추출물을 이용한 멜라닌 생성억제와 피부의 멜라닌 · 홍반 값의 변화도. 아시안뷰티화장품학술지,

10: 291-297, 2012.

배인순, 심미자, 이주영, 김영철. 황백 열수추출물의 기능성 화장품 천연소재로서의 활용 시험. 대한미용학회지, 8: 1-8, 2012. 송정희, 김봉조, 최은정. 20,30 대 여성들의 세안 실태와 클렌징 오일이 얼굴 피부건조 개선에 미치는 영향. 아시안뷰티화장품

학술지, 8: 11-20, 2010.

엄미정, 김치선, 진성용, 김은지, 김정만, 송영주. 얌빈 재배 시 직파와 육묘이식에 따른 구근 특성 및 수량성 비교. 원예과학

기술지, 34: 73-74, 2016.

오나카 타다카츠. 자외선이 건강에 미치는 영향. 한국의류산업학회지, 4: 310-316, 2002.

이송희, 이선, 이수진, 이수아, 김옥진. 천연물 유래소재들의 피부 미백 및 항산화 효과에 대한 연구. 한국동물매개심리치료학 
회지, 2: 35-41, 2013.

이아름, 김교남, 김혜옥, 송원정, 노성수. 얌빈 추출물의 항산화 효능과 멜라닌 생성 억제효과. 대한본초학회지, $32: 57-64$, 2017.

이애순, 명은진. 20 대 여성의 피부건강관리에 대한 지식 및 행위에 관한 실태조사: 충주, 원주에 거주하는 20 대 여성을 중심으 로. 한국미용학회지, 8: 105-120, 2002.

이주영, 양현, 최원철. 규질점토암을 이용한 머드팩의 제조와 안전성에 관한 연구. 한국미용학회지, 11: 73-85, 2005.

장순남, 김금란, 김계숙, 이유미. 20대 여대생의 안면 피부관리가 피부상태에 미치는 영향. 한국피부미용향장학회지, $6: 123-$ 130, 2011.

지선옥. 상백피 추출물의 항산화 활성 및 미백효과. 한국자원식물학회지, 22: 145-151, 2009. 


\section{中文摘要}

\section{含山药豆提取物面膜的皮肤改善效果}

李아름 ${ }^{1}$, 金惠玉 $^{2}$, 宋原貞 $^{3}$, 閔惟泓 $^{4}$, 盧盛洙 $^{1 *}$

${ }^{1}$ 大邱韩医大学本草药理学科, 大邱, 韩国

2 庆南大学护理学科, 庆尚南道昌原市, 韩国

3尚州市农业技术中心，庆尚北道尚州市，韩国

${ }^{4}$ 大邱韩医大学美容产业学科, 庆尚北道庆山市, 韩国

目的：在以前的研究中, 曾表明山药豆提取物具有抗氧化和抗黑色素生成的效果。因此本研究探讨含有山药豆提取物面 膜的皮肤改善效果。方法: 按照选拔基准，最终选拔20岁左右女性为研究对象。对15名的研究对象每周3次 10 min 敷含有 山药豆提取物的面膜, 进行5周。测定了油脂、水分、红斑以及黑色素含量, 并调查主观皮肤状态改善效果。结果: 使用 面膜5周之后, 油脂、水分含量明显增加。特别是, 红斑和黑色素含量显著改善。通过问卷调查得出, 主观皮肤状态如干 燥和色素沉着等问题中获得高满意度。结论: 研究结果表明, 含有山药豆提取物面膜的使用, 能改善皮肤油脂、水分、 红斑和黑色素，在临床方面可以作为优秀的美容原料。

关键词: 山药豆，面膜，油脂含量，黑色素含量，皮肤改善 